\title{
Theological principles of communicative (Takfiri) thought
}

\author{
Ruhollah Alinejad Omran ${ }^{1}$ and Mousa Abdollahi, ${ }^{1, *}$ \\ ${ }^{1}$ Allameh Tabataba'i University, Dehkade-ye Olympik, West Hemmat Highway, Tehran, \\ 1489684511, Iran
}

\begin{abstract}
Looking at the calamities that have inflicted on the Islamic society by its atheistic currents, it is indispensable to confront and fight against it radically. Getting acquainted with the principles of the criticism of the aforementioned currents is of great importance. Among the contemporary seditions that have led to the separation of the Muslim ummah is the excommunication (Takfir) of Muslims by each other in which one religion is accused of blasphemy by another school and they have to hear the most severe and most vulgar words and ultimately due to an imaginary crime of blasphemy and shirk, they will be slaughtered by the claimant. However, the process of excommunication, as it should be, does not emphasize on the debate and assumes that the insistence on excommunication and sins of other religions is to revive the tradition and to destroy heresy (Bid'ah); therefore it is necessary for Islamic researchers who consider fairness in their scientific discussions to understand the basics of the excommunicative movement to defend the legitimacy of Islam and Shi'ism and also protect them from falling into the trap of fallacies. Accordingly, the present article seeks to clarify the principles of excommunicative thought criticism in terms of Quranic verses, Hadith, Sirah Mutawatir (successive conducts) and rational arguments. Determining the position of conflict on matters such as intercession and resort (Tawassul) to prophets and imams while addressing issues such as the attribution of shirk to Shia, non-adherence to the well-known sirah of Salaf of blessing and visiting the tombs, and the need to pay attention to good heresy (Bid'ah) in the form of a superior controversy are considered the principles of excommunicative (Takfiri) thought criticism.
\end{abstract}

\section{Introduction}

The enemies of the Islam seek a new sedition against it at any time, sometimes with the creation of military forces, sometimes with the creation of a doubt and ideological divide. Among the contemporary seditions that have focused on the separation of Islam is the excommunication (Takfir) of Muslims by each other in which one religion is accused of blasphemy by another school [9] and to hear the most severe and most vulgar words and ultimately due to an imaginary crime of blasphemy and shirk, they will be slaughtered by the claimant. The issue of Salafism and the threat from it is very relevant and many articles

*Corresponding author: mabdollahi@atu.ac.ir 
have written about it. For example "Who are "the" Salafis?" [9], "Taking people as they are: Islam as a realistic utopia in the political theory of Sayyid Qutb" [1],"Cultural memory of the pious ancestors (salaf) in al-Ghazālī" [6], "The politics of popular religion: Sufis, Salafis, and Muslim Brothers in 20th-century Hamah"

The excommunication current, as it should be, does not emphasize debate and dialogue, but it only blows its empty drum and it just accuses others. They claim that their persistence on the excommunication and sins of other religions is due to reviving the tradition and destroying heresy (Bid'ah); therefore, Islamic scholars who consider fairness in their scientific discourses need to know the principles of the excommunicative process criticism in order not to get caught in the trap of excommunicative scholars' fallacy when they discuss with him. It is worth noting that the text has focused on the thought of the excommunicative current, which Wahhabi scholars- consciously or ignorantly - will be considered as the source of excommunicative thought and, as a result, the purpose is to revise the principles of the aforementioned thought. Determining the position of the conflict, the separation of the Shiites from shirk are among the principles of excommunicative thought criticism.

\section{Results}

\subsection{Determining the position of the conflict}

Understanding the position of scientific debate is one of the most important bases of any scientific debates. The process of arguing with the excommunicative scholar is not an exception. They do not deny the issue of resorting, intercession and supplication to the body and clothing of the prophet (PBUH) to satisfy the blessings at the time of his life [5]. Therefore, arguing with them on the basis that proves the permission of intercession, supplication and so on during the lifetime of the prophet (PBUH) by prophet himself is nothing but an emphasis on religious affiliations. For example, the Quran states:

"wa lamma waqae ealayhim al-rajzo qaloo ya mousa odo lana rabbak bema ahda laen andak kashafta anna al-rajza lanomenan laka wa lanorselna maak bani sraiel " (Aeraf /134) (When calamity dominated them, they said, "O Moses! Ask God to treat us with the covenant he has made with you! If you remove this calamity from us, surely we will believe in you, and we will send Israelites with you).

In order to prove the prophet's (PBUH) mediation to the Israelites' supplication to Moses (PBUH), some have referred to aforementioned verse; however, due to the position of conflict, Wahhabis will not be satisfied.

Reasoning to similar verses would have the same effect. Abdul Rahman Al Sheikh writes:

"Al-esteshfae be al-rasoul fi hayat, faenamma howa badaae sale allah aleyhe wa sallam wa daava mostajeb wa amma baada vafate la yajvaz al-esteshfae"

"There was a request for intercession from the prophet (PBUH) at the time of his life, which was answered by his prayer, but after his death, seeking intercession is not permitted."

Therefore, one of the principles of excommunicative and Salafist thought criticism is not to get out of the conflict. For example, during the discussion of resorting and intercession, one should rely on evidence to substantiate what has been said after the death of the prophet (PBUH). 


\subsection{Shiite Separation from Shirk}

The Takfiris consider predominantly Shiite and Sunni Muslims as pagans and consider their blood as Mubah and, despite being strictly old fashioned in Islamic thinking and beliefs, they are dominated by extreme superiority [8-677-678]. Although it is not permissible to excommunicate those who believe in the triple principles of monotheism, prophecy [1-264], and resurrection, in reference to the verses that have been addressed to the polytheists, Wahhabi scholars want to prove that resort, intercession and supplication after the death of the prophets and the Imams are shirk. As a result, during a fallacious process, the Shiites are called a polytheist. Of course, they will have no reason to accuse Shiites to shirk [5]. They say:

"Doa al-nabi nadava wa al-esteqasa be baade mota fi qaza al-hajat wa kashaf al-karbat shirk, yakrojo men malla al-islam sawa kan zaleka end qabro omo baeeda anh"

Therefore, they use the verses related to the polytheists. One who is debating or criticizing excommunicative and Wahhabi thoughts should take note of this and emphasize the distinction between Shiite and polytheist thoughts. For example, Ayatollah Makaram Shirazi, in the rejection of verse:

"Laho davit al-haq qa al-zina yadoona men done la yastajiboona lahom beshaye ella kabeset kafayya ela al-mae leyabloqa faho wa ma howa bebaleqe wa ma doa al-kaferina ella fi zalal" (Raad 13) (the rightful invitation is His! And those (polytheist) who call upon other than Allah, are not responded to their calls. They are like those who open their hands to water so that water can reach their mouth, and it will never reach it! And the prayer of the disbelievers is only in error.)

Believes that matters like intercession and resort that the Shiites believe in:

"The Wahhabis, who attribute shirk and infidelity to us because of these prayers and resorts, are sorely mistaken and do not understand the true meaning of shirk and infidelity, as believers in prayer and resort, however, do not regard the elders and the Imams as partners with God, but they are made submissive to God".

The point is that the Wahhabis must answer that what had not been considered shirk until the prophet's (PBUH) life, what has happened that after the death of the prophet (PBUH), it was considered as shirk. Wahhabis has to answer whether there has been a change in the essence of the inviter who called prophet (PBUH) or in the essence of the invited person who is the prophet (PBUH) or in prayer which is the same supplication and intercession? [23-17]. The Shiites consider it negatively because the believers who blessed the prophet (PBUH) and after his death, they blessed the prophet's grave and works had a completely different view of the polytheists. Otherwise how can they be justified? Especially in the belief that all companions are impartial.

Essentially, the difference between a believer's and a polytheist's perspective can be summarized in some cases:

First: The polytheist has no argument for his shirk to provide it, but the believer's school is not like this. The Quran says:

"Wa man yadaa maa allah elaha akar al-borhana laho beh..." (Momenoon /517) (And whoever considers another idol with God - and certainly has no reason to do so).

Second, the polytheist follows his speculation and senses. This is not the case with the believer. The Quran says:

"En hiya al- asmae samaytomoha antom wa abaokom ma anzala allah beha men soltane en yatabeoona al-zanna wa ma tahwa al-nafso wa laqad jaahom men rabbehem al-hoda" (Najm/23). (These are just the names that you and your fathers gave them (nonsensical and meaningless names), and God has never revealed to them any reasons; they follow only baseless speculation and senses while their Lord has guided them)

Third: The polytheist blindly imitates his ancestral religion, but the believer has turned to his religion with knowledge and certainty. The Quran says about this: 
"Wa 'iidha qeel lahum taealawa 'iila ma 'anzal al-'llah wa 'iilaa al-rasul qalu hasbuna ma wajadna ealayhe aba'ana wa law kan abawuhum la yaelamun shayyaan wa la yahtaduna" (Maede/104) (And when they are told, "Move to what God has sent down, and to the Messenger!" They reply: "It is enough what we have learnt from our fathers!" What if they knew nothing about their fathers, and they were not guided (Do they follow them again)?!

Fourth: The polytheist's view toward the partners along with God is an independent view and it is in the width of God. The Quran states in their surprise of divine monotheism:

"Wa eajibuu 'an ja'ahum munzer minhum wa qal al-kaferun haza saher kazzab* a jaeal al-alehe 'iilhaan wahedaan 'inn haza lashay' eujabun" (sad/ 4- 5). (They were surprised that a prophet came to them from among them, and the polytheist said: This is a very false sorcerer! * Has he made one God for all these gods? This is truly a strange thing!)

The polytheists are; in fact, worshiping partners of God, consider each of them as the principal of their lives. In other words, they attribute God-like characteristics to the partners of God [5].

Interestingly, referring to the question of whether or not misbaha is heresy and shirk, the Wahhabi scholar points to the difference mentioned and he answers that misbaha is not heresy and shirk because the person who has a misbaha, does not intend to worship it. Finally, when asked about the difference between misbaha and blessing or prostration on the ground, though they all share the motive of not worshiping them, Wahhabi's answer is nothing except fanaticism.

The contradiction between Wahhabi's thought is not concealed for a fair scholar. All Wahhabis respect and kiss "Black Stone"( Hajur al-Aswad), when they are told that it is no more than a stone, they respond, the prophet (PBUH) kisses it, we follow him and we kiss, too! Do they mean that the prophet of Allah (PBUH) has made this an exception, allowed them to do shirk or does the kiss not refer to shirk?! At this point, they are silent and have no answer.

Fifth, the polytheists seem to worship idols beside the worship of Allah for getting close to Him, as it is stated in the Quran:

"alaa lellahe la din al-kales wa alazin otakezoo men dunih ma naaboadohum ela leyaqrobonaha 'iilaa allah zoulfa 'ana allah yahkumahum beynohom fi ma hom fih yaktalifun 'en allah la yahdi man hu kazeb' koffar" (zomr/ 3). (Be aware that pure religion belongs to God, and those who consider non-gods as their god, and their reason was, "We do not worship them but to get us closer to God", Allah judges what is in dispute in doomsday; Allah will never guide the one who is a liar and a disbeliever).

But as it is mentioned at the end of the verse, they are liars. Also, their hearts are troubled when they speak of God's unity. The Quran has revealed their heart and says:

"Wa eza zuker allah wahdah eshmaezat qulub alazin la yumenun belakareh, wa eza alazin men donehi eza hom yastabsheroun" (zomr/ 45). (When God's unity is mentioned, the hearts of those who do not believe in the Hereafter are touched (and hated), but when other gods are mentioned, they become happy).

Ayatollah Makarem Shirazi has also pointed out the difference between the polytheistic and the faithful viewpoint. He states that the Shia's belief is the same as that stated in the Quran about Jesus (PBUH):

"Wa ez takluq men al-tayn kahayyat al-ttayr bezna fatanfukha fiha fatakun tayraan beezni wa tubri al-akmah wa al-abras beezni wa ez tukrij al-maota beezni ..." (mayidh/ 110). (When, at my command, you made something like a bird from the clay, and you breathed in it, and it became a bird at my command; And at my command, you heal the congenital blindness and vitiligo disease; You also raised the dead at my command ...).

In the verse mentioned, the resurrection of the dead, the healing of the sick, the creation of the birds, are all attributed to Jesus Christ, but all of them were by the permission of God Almighty. 
He also mention in somewhere else:

"When resorting to the prophet (PBUH) or the imams (PBUH) or the Quran, and so on, Shia never worships them, as the pagans considered idols as shaafi and intermediate by worshiping them. Instead, we call on prophets or imams to use their own honour and dignity in the presence of God and ask God for a solution of our problem" [4].

Finally, the summary of Wahhabism is that resorting does not fit with unity of acts (tawhid al-afaali) because something except God has been effective in this world. The answer is:

"The Shiites ... do not consider what is resorted to in their prayers in width of God but they consider these resorts effective in the length of creation and with the permission of God, and this does not contradict with unity of acts (tawhid al- afaali). If we were to say that the prophet and the imam - God Forbids - were independently influential, it was shirk" [4].

In view of the differences mentioned between the polytheist and the believer's views, the Shia who considers himself to be a believer and does not accept any of the polytheistic views, and he likes a believer who believes in one God and accepts resorting, intercession, blessing and the like to the prophets and imams, only by divine will and permission.

\subsection{Emphasis on the Verses and Narrations of the Prophets' Life in Purgatory}

As stated in the preceding section, Wahhabis has three ways to accuse the Shia of being shirk, or he must be able to prove that the essence of the believer who called and exhorted him during the prophet's lifetime, has changed to polytheism after the death of the prophet (PBUH). This was eliminated despite differences between the worshipers and the polytheists. The second way for the Wahhabi scholar, which is the origin of many excommunicative movements, is to prove the change in the essence and nature of the prophet (PBUH), i.e., the person who is called by the believer. That is, before his death, he was able to do works, but after his death, he became lifeless like objects and material and was unable to respond to the believer [5].

Examples of Quranic arguments can be cited in the following verses:

"wala tahsabann alazin quteluu fi sabil al-llah 'amwataan bal 'ahya' eind rabbihim yurzaquna* farihin bima atahum al-llah men fazilah wa yastabshirun be alazin lam yalhaquu bihim men kalfihim 'alla kaof ealayhim wa la hum yahzanuna* yastabshirun beniemat min al-llah wa fazl wa 'ann al-llah layuzie 'ajr almuminin" (Aleimran/ 169- 171).( (O Prophet!) Never think those who are killed in the cause of God are dead! Rather, they are alive, and they are fed by their Lord. They are happy because of the many blessings God has bestowed on them from His grace; and they are happy for those who have not yet joined them [the Mujahideen and future martyrs]; ( (Because they know their prominent status in the world) they have no fear, nor will they grieve. And they rejoice in the blessings of Allah and His bounty (to them). And (they see) Allah does not waste the reward of the believers (neither the reward of the martyrs nor the reward of Mujahideen who did not become martyrs)

The verse mentioned refers to the lives of the martyrs and their feeding in the presence of God which is accompanied by spiritual effects such as happiness. God has raised the issue of their lives because of His blessings and generosity upon them, and has thus rejected the dominant thinking in the early days of Islam that the death of a martyr is the end of his life. So, is it possible to imagine that martyrs are alive after death but prophet (PBUH) who is superior to a martyr is not alive after his death?

Even if such a preference is not accepted for the prophet (PBUH) over the martyr, there are many narrations that if anyone does something special, the dead is considered martyr, such as saying three times in the morning: aozo bi-allah al-samie al-alim men al-shaytani 
al-rajimi, then reciting the last three verses of Hashr Surah, ... if he dies that day, he is considered the martyr. Does the prophet (PBUH) with all those efforts have a lower rank than such a person to decay his body in the grave and become a stone and a stick after his death? It is also stated in another narration that anyone who dies for the love of Muhammad (PBUH) and his family is a martyr. Who is more in love with the family of prophet than prophet himself? According to this hadith, the prophet (PBUH), if he is not superior to the martyr, he has died to the rank of martyr and is subject to the verse of martyrs' life in Purgatory.

Finally, it can be said that due to purgatory and hereafter life of the dead, the suspicion of his inability to respond to human desire, especially concerning the prophets, has no source other than the materialistic worldview.

Wahhabi scholars differ from Sunni scholars in terms of a scientific standpoint, but Wahhabis do not necessarily reject correct hadith. As a result, we can silence Wahhabi scholars by quoting the views of Sunni elders about the narrations of the prophets' lives in Purgatory. As an example, it is quoted in the book of Suyuti that he considers hadiths mentioned to be successive. Ibn Qayem has also quoted dozens of narrations of the purgatory life of the dead.

\subsection{Application of a Superior Controversy in the Criticism Process}

How to deal with the person and the way of discussion after strong arguments will have the most profound impact on the person in a scientific debate, as many who are thorough in discussions and knowledgeable on scientific issues but are not aware of the "superior controversy " method. So, they are less likely to penetrate their hearts in conversation with others. In the critique of excommunicative thought, a "superior controversy" can also pave the way for debate. In order to achieve this, two types of superior controversies regarding Wahhabism principles are suggested. Each of these will be discussed below.

A) Expressing the Sirat of the Companions in Resort and Blessing according to their Justice

The justice of the companions is one of the important foundations of the Sunnis who today, based on this false basis, consider many Muslims and Shiites as polytheist with the accusation of the companions' damnation and take into consideration their blood as wasting. Of course, it is necessary to explain that although the majority of the Sunnis considers justice for all the companions, the Shiites and some Sunni intellectuals do not accept that. However, Wahhabis have accepted the promise of justice for the companions and it deserves to use this basis in the superior controversy with them. For example, it can be referred to the case of the famine in Medina and Ayeshe's order to people to make a rift in the grave of the prophet (PBUH) towards the sky and the rain. Also the case of the prayer of a man who goes to the grave of the prophet (PBUH) during the time of water famine at the time of Omar's caliphate, saying: "Oh Prophet of God, give water to your nation that is perishing.

B) Demonstrating Resort and Blessing and so on as Good Heresy

Another superior controversy in the path of criticism of excommunicative thought is the use of the term heresy. One of Wahhabi's weapon is an allegation of shirk to Muslims that can be solved by differentiation and explanation between shirk and faith, and another method is heresy [4]. Heresy can also be solved by expressing the manner of the prophet (PBUH) and his companions and the fatwas of the great scholars. The concept of heresy has gone so much wrong that even the life system of its world has been disrupted. Ayatollah Makarem Shirazi has made it clear that if it's mentioned in the history of Wahhabism that a group of them would even oppose the bicycle and call it the rider of Satan or when Saudi leaders used the telephone line in order to get informed of the military headquarters, 
Wahhabis tore and destroyed the lines and called it heresy, it is a very stupid thing that has nothing to do with the concept of heresy that has come into Islamic jurisprudence, and unfortunately their history is full of such things. But their recent prophecy can also be used in the superior controversy because if any proof is given of the non-heresy of resort, blessings and pilgrimage and it is not accepted, with the first acceptance of the Wahhabi basis, that is, the acceptance of aforementioned subjects as heresy, it will be tried to prove the good heresy as all the Sunnis have accepted the good heresy in Tarawih prayer [5]. Therefore, Wahhabi must either accept the Tarawih prayer as Omar's heresy and it is AlNass wa L- ijtihad, or accept the pilgrimage as a good heresy. Ayatollah Makarem Shirazi has also noted that modernisms that are not ascribed to religion and in other words, "customary heresy" are never forbidden. For example, taking celebratory ceremonies in the birthdays of the great elders of Islam or mourning for their martyrdom and passing away for the sake of devotion without referring to the sacred law is not problematic but also promotes religious and social issues or building mosques with minarets and domes and numerous altar houses and libraries and Quran and Ahkam classrooms and the like, although no specific narration has been introduced, and no one does it as a specific religious order, all of which are permissible, but many can be considered as God symbols in general or in the creation of a good tradition which is mentioned in the verses and narrations.

\subsection{The Importance of the Application of Comparative Interpretation}

One of the most important principles of criticism of excommunicative thought is the application of comparative interpretation for the verses to the Wahhabi arguments. Comparative interpretation is an interpretation that examines the arguments and their rationale for interpreting each of the verses between Imamate and Sunni schools of thought and to choose the correct interpretation or reject both and select the third interpretation. In other words, comparative interpretation means the inter-disciplinary or inter-religious and examination of the issue on both sides. One of the verses that can be interpreted comparatively in criticizing excommunicative thought, relying on its comparative interpretation, is a verse that considers the polytheists as dead:

"wa ma yastawi al'ahya' wa al'amwat 'inn al-llah yusmie man yasha' wa ma 'ant bemusmie man fi al-qubur" (Fater/ 22). (And the dead and the living are never alike! God delivers His message to whomever He wills, and you cannot give a word to those who are asleep in the grave!)

The Wahhabis believe that the dead do not hear anything and are idle like idols and that the grave in the above verse refers to a clay hole in graveyard [5]. Dr. Najjar Zadegan, who has several works on comparative interpretation, believes that most of the old and new commentators believe that the verse is a simile and wants to consider the polytheist as dead people who do not hear, i.e. the polytheists' hearts are dead as the body of the dead in the grave and divine words and verses have no effect on them. By comparing the interpretations of the commentators and the existing probabilities and the rarity of the Wahhabi's point of view, it is possible to point out that the Wahhabis' interpretation of the above verse may be inaccurate. Ignorance of the comparative interpretation method can lead to ignorance of the understanding quality of the verses of the opposite side, and the scientific discussions will not succeed.

\section{Conclusion}

What was said was the material that came to mind of the writer, and it is alleged to cite the above-mentioned cases as deductive induction. However, methodological discussions 
among Shiites and extremists such as some Wahhabis, and in particular the excommunicative (Takfiri) currents, can accelerate these debates and convince the disputing party sooner if he is fair or if he insists on being wrong, he can be rectified. Focusing on the position of conflict, the separation of Shiites from Shirk, the evidence of the prophets' purgatory life, the superior controversy in the process of criticism, the application of comparative interpretation, are the principles of criticism of excommunicative thought.to this method, it is necessary to suddenly remove one bearing element and calculate the rest of the building so that it does not collapse. So the work of the damaged structure is subjected to detailed analysis, while the cause of local destruction is not necessary to know...

\section{References}

1. A.F. March, American Political Science Review 104(1), 189-207 (2010) DOI: $10.1017 /$ S000305541000002X)

2. I. Weismann, International Journal of Middle East Studies 37(1), 39-58, (2005), DOI: 10.1017/S002074380505004X

3. E. Kazemi, Journal of Wahhabism Review Seraj Munir 12(4), 95-119 (2013)

4. N. Makarem Shirazi, The Wilayat Verses of the Quran (Nasl Javan, Qom, 2007)

5. F. Najjarzadegan, Investigation and Evaluation of the Evidence of Resort, Intercession, Blessing, and Pilgrimage (Zaaer Astan Quds, Qom, 2012)

6. O. Anjum, Numen 58(2-3), 344-374 (2011) DOI: 10.1163/156852711X562344

7. M. Qeraati, Television Program Lessons from the Quran, Broadcast from the Islamic Republic of Iran, Channel One (2013) http://www.gharaati.ir/show.php?page=darsha\&id=2220

8. M. Rezaie Isfahani, Interpretation of the Quran (Publications of Quranic Interpretation and Research Studies, Qom, 2008)

9. S. Damir-Geilsdorf, M. Menzfeld, Journal of Muslims in Europe 6(1), 22-51 (2017) DOI: $10.1163 / 22117954-12341337$ 